\title{
Підвищення експлуатаційних параметрів деталей двигунів внутрішнього згоряння
}

\author{
Є.А. Фролов ${ }^{1}$, С.В. Попов ${ }^{2}$, О.В. Сидорчук ${ }^{3}$ \\ ${ }^{1}$ Національний університет «Полтавська політехніка \\ імені Юрія Кондратюка» (м. Полтава, Україна), \\ 2,3 Полтавський державний аграрний університет (м. Полтава, Україна), \\ email:1 kaf054@i.ua; ${ }^{2}$ stanislav.popov@pdaa.edu.ua, ${ }^{3}$ famcruel@gmail.com
}

\begin{abstract}
Робота присвячена підвищенню надійності та довговічності деталей циліндро-поршневої групи двигунів внутрішнього згоряння. Зміцнення деталей машин можливе за рахунок застосування спеціальних технологічних процесів. Сучасні матеріали та покриття повинні задовольняти високим робочим температурам і навантаженням. Хромування, борування та іонно-плазмове напилення не задовольняють встановленим вимогам якості. Алюмінієвий поршень зазнає руйнувань в районі головки. Це проявляється у накопиченні шпарин, каналів, слідів вимивання сплаву. Окрім цього, внаслідок нагрівання, втрачається міцність алюмінієвого сплаву більше, ніж у 2 рази.

Запропоновано створення та застосування покриття, яке б витримувало робочі температури понад $2000^{\circ} \mathrm{C}$, а також ударно-пульсуючі навантаження. Пропонується детонаційно-газовий метод напилення. Він характеризується універсальністю матеріалів: від полімерів до тугоплавкої кераміки, любі метали і сплави. Напилені частинки володіють високою кінетичною енергією. Покриття характеризується високою міцністю, яка сягає $180 \ldots 200$ МПа, твердістю HRCe 60, мінімальною шпаринністю. Температурний вплив при напиленні на заготовку незначний. Запропоновано послідовність підготовчих операцій. Зміцненню підлягали поршень та жарове кільце на детонаційно-газовій установці «УН-102». Застосовувався маніпулятор, що використовує енергію пострілу установки. Отримані поверхні характеризуються регулярною макроструктурою (хвилястістю). Нанесенню підлягав нікель-алюмінієвий сплав. Товщиною покриття - 150...270 мкм, твердість HV 550, адгезія до основи - 94...100 МПа.

Результати досліджень на деталях циліндро-поршневої групи засвідчили зниження робочих температур, внаслідок припрацьовування покриття та якісного ущільнення камери згоряння. Довговічність кілець становить $1,6 \cdot 10^{6} \ldots 2,3 \cdot 10^{6}$, що свідчить про значне підвищення опору втомі та ресурсу роботи. Запропонована технологія $є$ придатною та рекомендується до впровадження у серійне виробництво.
\end{abstract}

Ключові слова: детонаційно-газове зміцнення, поршень, жарове кільце, напилення, покриття.

Вступ. Надійність та довговічність роботи деталей циліндро-поршневої групи двигунів внутрішнього згоряння, як для техніки сільського господарства та інших галузей, суттєво впливає на життєвий цикл самого двигуна. Перспективним напрямком підвищення стійкості та довговічності цієї групи деталей $\epsilon$ нанесення на їх робочі поверхні зміцнювальних покриттів.

Постановка проблеми та ї̈ актуальність. У сучасному машинобудуванні особливе місце займають технології, що пов'язані з наданням робочим поверхням деталей машин необхідних властивостей, що забезпечують підвищення їх експлуатаційних характеристик [1-3]. Задача подальшого форсування двигунів внутрішнього згоряння пов'язана перед усім із необхідністю покращення фрізико-технічних властивостей деталей циліндро-поршневої групи за рахунок застосування нових жароміцних матеріалів та сучасних покриттів, що задовольняють температурі та навантаженням в конструкціях двигунів внутрішнього згоряння.

Аналіз результатів останніх досліджень та публікацій та виділення невирішених раніше частин загальної проблеми. Існуючі технології створення захисних покриттів (хромування, борування, іонно-плазмове напилення) не задовольняють встановлені вимоги до деталей двигунів внутрішнього згоряння, що працюють при високих температурах та значних навантаженнях [4-5].

Поршень, виготовлений з алюмінієвого сплаву АК4-1 із заштампованим кільцетримачем та камерою згоряння із жароміцної сталі під час роботи зазнавав впливу продуктів згоряння із максимальною температурою $2000^{\circ} \mathrm{C}$ та пульсуючим тиском $0,1 \ldots 10$ МПа. Під час роботи в умовах багатопаливності відбувається руйнування головки 
поршня (торцева і бічна поверхні) та кромок камери згоряння. При огляді (після випробувань обкатки обсягом 500 годин) встановлено, що пошкоджені ділянки являють собою накопичення шпарин та каналів зі згладженими стінками та слідами вимивання сплаву. Таким чином, можливо припустити, що руйнування відбувалося за кавітаційно-ерозійним механізмом [4].

Окрім того, в результаті нагріву головки поршня до температури $450^{\circ} \mathrm{C}$ відбувається втрата міцності алюмінієвого сплаву - твердість після випробування, виміряна поблизу поверхні головки, склала НВ 52...56 порівняно із початковою HB 121...126 [4]

Таким чином, захист поверхонь поршня, які зазнають пошкоджень від впливу високотемпературного газового потоку є вкрай актуальною задачею.

Формулювання мети роботи. Метою роботи було створення та застосування покриття, на підставі попереднього аналізу технологій, яке б витримувало під час роботи температури понад $2000^{\circ} \mathrm{C}$, а також діючий на нього ударний пульсуючий тиск.

Викладення основного матеріалу дослідження. Як засвідчили порівняльні випробування найбільш прийнятною $є$ технологія і обладнання, що здійснює детонаційно-газове зміцнення.

Детонаційно-газовий метод напилення дозволяє не лише відновлювати робочі поверхні виробів та деталей, але й суттєво підвищити їх експлуатаційний ресурс. Для нанесення покриттів цим способом можуть бути використані практично любі матеріали: від полімерів до тугоплавкої кераміки, а також любі метали і сплави. Розмір частинок порошку, що застосовується для нанесення покриттів, зазвичай знаходиться у межах 5...100 мкм залежно від матеріалу порошку та потрібних параметрів шпаринності покриттів. Частинки, що напиляються, володіють надзвичайно високою кінетичною енергією. Це визначає рівень міцності покриттів. Він на порядок перевищує міцність зчеплення покриттів, що отримані іншими газотермічними та газоелектричними способами. Міцність покриттів може сягати $180 \ldots 200$ МПа, залежно від матеріалу покриття та деталі. До того ж детонаційно-газові покриття мають мінімальну шпаринність - до 0,5...1,0\% (газополуменеві - 10\%, а плазмові - 2\%). При цьому, як правило, при формуванні покриття температура деталі при напиленні залежить від ії розмірів, не перевищує 530 К, що відповідає низькому відпалу. Внаслідок малої тривалості процесу напилення, температурний вплив незначний. Відсутня деформація деталі, що підлягає напиленню.

До особливостей даного способу також слід віднести:

- можливість плавного та стійкого регулювання параметрів процесу в широких діапазонах. Це дозволяє для кожного матеріалу встановити найбільш оптимальні режими напилення;
- застосування дрібнодисперсних композиційних матеріалів для напилення дозволяє формувати покриття із шорсткістю від 10 до 20 мкм, що в деяких випадках не вимагає додаткової механічної обробки;

- висока енергія продуктів детонації, що прискорює частинки, і підвищує їх температуру дозволяє формувати покриття із тугоплавких матеріалів не лише на металевих деталях із твердістю поверхні $\mathrm{HRC}_{\text {e }} 60$ та вище, але й на неметалевих матеріалах (скло, кераміка, дерево, картон та ін.).

Перед напиленням необхідно забезпечити виконання наступних підготовчих операцій:

- деталі повинні бути остаточно механічно оброблені окрім місць, що підлягають зміцненню. В цих місцях повинен бути видалений шар металу, що дорівнює товщині зміцнювального покриття;

- підготовка поверхні, зберігання і транспортування підготовлених під зміцнення відбувається у приміщенні при температурі не нижче $18^{\circ} \mathrm{C}$ та відносній вологості не вище $75 \%$. При цьому не допускається наявність у навколишньому середовищі речовин, що сприяють корозії поверхонь, що зміцнюються;

- поверхні зміцнення підлягають струйно-абразивній обробці в спеціальній камері під тиском стисненого повітря 0,4...0,6 МПа, відстань від зрізу сопла повітряного пістолета до оброблюваної поверхні 40..70 мм, кут нахилу потоку $60 . . .90^{\circ}$;

- поверхні, що не підлягають зміцненню, захищаються від впливу струйно-абразивної обробки, а також подальшого напилення, спеціальними екранами;

- після струйно-абразивної обробки відбувається обдування стисненим повітрям для видалення частинок абразиву;

- якість підготовки поверхні деталі під зміцнення контролюється зовнішнім оглядом із застосуванням лупи 4-кратного збільшення. Шорсткість поверхні повинна бути Rz 80...100 за ГОСТ 2789.

Було зміцнено дослідну партію деталей двигунів внутрішнього згоряння - поршень та жарове кільце. Напилення виконано на детонаційно-газовій установці «УН-102», до складу якої входить маніпулятор, що забезпечує синхронне переміщення деталі під час фрормування покриття. Загальний вигляд установки для детонаційно-газового зміцнення «УН-102» представлено на рис. 1, а технічна характеристика в табл. 1.

Жарове кільце являє собою кільце манжетного типу L-подібного перерізу. Одним своїм елементом - манжетою, контактуюче із циліндром, а другим - полкою - із поршнем. Таким чином здійснюється ущільнення камери згоряння.

Під час роботи жарове кільце зазнає термічних та механічних навантажень. Температура жарового кільця становить від $300^{\circ} \mathrm{C}$ на манжеті до $420^{\circ} \mathrm{C}$ на полці. Руйнування кілець в експлуатації починається завжди з манжети та має втомний характер. 


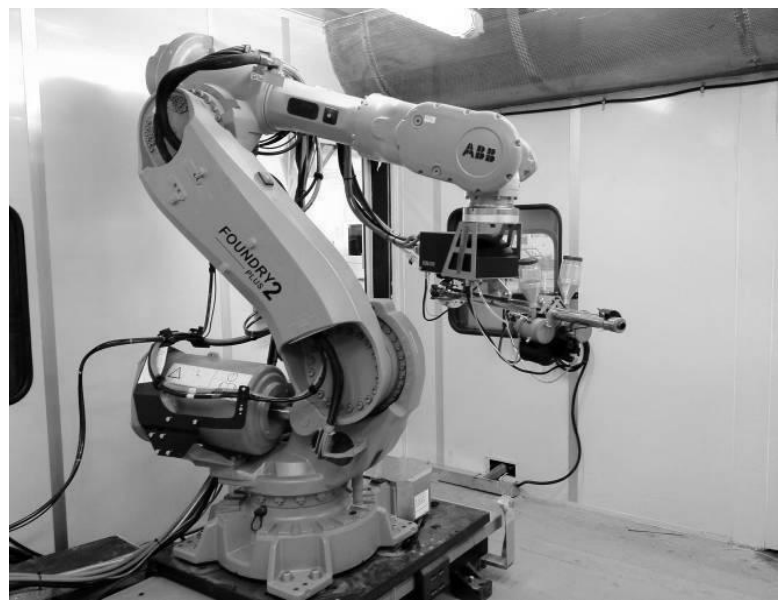

Рис 1. Установка детонаційно-газового зміцнення «УН-102», встановлена на промисловому маніпуляторі

Таблиця 1. Технічна характеристика установки «УН-102»

\begin{tabular}{|c|c|}
\hline Параметр & Значення \\
\hline Калібр ствола, мм & 20 \\
\hline Довжина ствола, мм & $640 \ldots 1840$ \\
\hline $\begin{array}{l}\text { Швидкострільність, } \\
\text { цикл/с }\end{array}$ & до 15 \\
\hline $\begin{array}{l}\text { Подача порошку до } \\
\text { ствола }\end{array}$ & радіальна \\
\hline $\begin{array}{l}\text { Об’єм бункера доза- } \\
\text { тора, мл }\end{array}$ & 160 \\
\hline $\begin{array}{l}\text { Товщина покриття за } 1 \\
\text { постріл, мкм }\end{array}$ & $2 \ldots 20$ \\
\hline $\begin{array}{l}\text { Коесріцієнт викорис- } \\
\text { тання порошку }\end{array}$ & до 0,8 \\
\hline Робочі гази & $\begin{array}{c}\text { газоподібне паливо (аце- } \\
\text { тилен, пропан, водень), } \\
\text { кисень, азот (повітря) }\end{array}$ \\
\hline $\begin{array}{l}\text { Робочий тиск усіх га- } \\
\text { зів, МПа }\end{array}$ & $0,12 \pm 0,01$ \\
\hline $\begin{array}{l}\text { Співвідношення па- } \\
\text { лива та кисню у горю- } \\
\text { чій суміші }\end{array}$ & від 1:1 до 1:5 \\
\hline $\begin{array}{l}\text { Швидкодія: газових } \\
\text { клапанів, порошкових } \\
\text { дозаторів, мс }\end{array}$ & $12^{+2} ; 16^{+2}$ \\
\hline Система охолодження & водяна, замкнена \\
\hline Керування & $\begin{array}{c}\text { дистанційне, автомати- } \\
\text { чне, програмоване }\end{array}$ \\
\hline Напруга живлення, В & $380 / 220$ \\
\hline $\begin{array}{l}\text { Найбільша споживана } \\
\text { потужність, кВт }\end{array}$ & 5 \\
\hline Габаритні розміри, мм & $2500 \Leftrightarrow 644 \Leftrightarrow 1200$ \\
\hline Maca, кг & 360 \\
\hline
\end{tabular}

Дослідні поршні виконані без застосування жароміцної сталі для камери згоряння, тобто контур камери було виконано повністю з алюмінієвого сплаву, а гострі кромки камери згоряння мають заниження до центра [6].
Детонаційно-газовому напиленню було піддано зовнішню поверхню манжети жарового кільця. Напилення виконувалось із застосуванням оригінального маніпулятора, що використовує енергію пострілу детонаційно-газової установки.

Застосування даного маніпулятора дозволило отримати на поверхні жарового кільця покриття із суворо регулярною макроструктурою (хвилястістю). Це стало можливим завдяки високій точності ( $\pm 0,05$ мм) відтворення кроків напилення (інтервалів між одиничними плямами), розрахованими виходячи 3 форми плями напилення, що забезпечило формування шару покриття із мінімальним рівнем залишкових напружень і, що особливо важливо, суворо однаковим за усією довжиною кола жарового кільця.

Матеріал покриття - нікель-алюмінієвий сплав із товщиною покриття 150...270 мкм, твердістю - HV 550, адгезією до основи - 94...100 МПа. Після покриття кільце шліфувалося.

Порівняльні випробування щодо визначення температурного стану та втомної міцності жарового кільця, що здійснювались на підприємствівиробникові двигунів внутрішнього згоряння (Державне підприємство «Завод імені В.О. Малишева, м. Харків»), засвідчили наступне:

- на кільцях із зміцнювальним покриттям досягнуто (на $45^{\circ} \mathrm{C}$ на манжеті та $110^{\circ} \mathrm{C}$ на полці) зниження температури нагріву. Це зумовлено добрим припрацюванням покриття та, як наслідок, якісним ущільненням камери згоряння;

- кільця із ущільнювальним покриттям, випробувані циклічним навантаженням (змінюється за знакопостійним циклом), мали довговічність 1,6·106; $1,83 \cdot 10^{6}$ та 2,3 $10^{6}$ циклів - для серійних кілець.

Отже, можливо стверджувати про значне підвищення опору втомі жарових кілець, зміцнених детонаційно-газовим методом. Як наслідок, маємо підвищення ресурсу.

Висновки. Отримані напилені покриття із високими якісними показниками. На основі поведених досліджень можна зробити висновок про те, що нанесення зносостійких та міцних покриттів детонаційно-газовим напиленням на деталі циліндро-поршневої групи дозволить забезпечити економію металу та зменшити витрати на заміну даних деталей.

Тривалі стендові та натурні випробування дослідної партії поршнів із детонаційно-газовим зміцненням, проведені за повною програмою підприємства-виробника двигунів внутрішнього згоряння, показали повну придатність розробленої технології зміцнення для різкого підвищення працездатності двигуна. Дана технологія може бути впроваджена у серійне виробництво. 


\section{Література:}

1. Буденный М.М. Повышение ресурса и надежности деталей машин методом детонационно-газового напыления упрочняющих покрытий / М.М.Буденный, В.И.Власенко, А.Я.Мовшович // Вестник национального технического университета «ХПИ»: Сборник научных трудов. Харьков: НТУ «ХПИ», 2001. - №11. - С. 94-98.

2. Popov S. Improving the abrasive resistance of a slide frame in a mortar mixer / S. Popov, S. Gnitko, A. Vasyliev // Eastern-European Journal of Enterprise Technologies. - 2020. - №1/1(103). - Р. 6-14.

3. Попов С.В. Визначення характеристики газополуменевого напилення на основі багатофракторного експерименту / С.В. Попов // Машинознавство. - 2008. - №10. - С.45-47.

4. Этингант А.А. Особенности вакуумно-плазменного упрочнения режущего инструмента из быстрорежущей стали / А.А. Этингант, В.С. Стороженко, А.В. Колядинский // Передовой опыт. Киев, 1986. - № 12. - С. 27-30.

5. Богуслаев А.В. Исследование качества материала деталей после нанесения покрытий // Сборник научных трудов Национального аэрокосмического университета «ХАИ»: Сборник научных. - Харьков: НАУ «ХАИ», 2000. - № 21(4). - С. 55-66.

6. А.C. 1747728 СССР, ХНИИТМ F 02 F 3/14. Поршень из алюминиевого сплава для двигателя внутреннего сгорания / В.М. Темкин, Б.А. Подольский, В.Н. Власенко, Т.П. Гайдамака, А.Н. Косовцев, Э.С. Кулик (СССР). - № 943423; заявл. 12.09.88; опубл. 15.07.92, Бюл. № 26.

\section{References:}

1. Budenniy, M.M., Vlasenko, V.I., Movshovich, A.Ya. 2001. Increasing the resource and reliability of machine parts by detonation-gas spraying of hardening coatings. Bulletin of the National Technical University "KhPl", no. 11, pp. 94-98.

2. Popov, S., Gnitko, S., Vasyliev, A. 2020. Improving the abrasive resistance of a slide frame in a mortar mixer. Eastern-European Journal of Enterprise Technologies, no. 1/1(103), pp. 6-14.

3. Popov, S.V. 2008. Determination of gas-flame sputtering characteristics on the basis of multifactor experiment. Mechanical Engineering, no. 10, pp. 45-47.

4. Etingant, A.A., Storozhenko, V.S., Kolyadinskij, A.V. 1986. Features of vacuum-plasma hardening of cutting tools made of high-speed steel. Innovate experience, no. 12, pp. 27-30.

5. Boguslaev, A.V. 2000. Investigation of the material quality of parts after coating. Collection of scientific papers of the National Aerospace University "KhAl", no. 21(4), pp. 55-66.

6. Certificate of authorship 1747728 USSR. 1992. Aluminum alloy piston for internal combustion engine.

\title{
Аннотация
}

\section{Повышение эксплуатационных параметров деталей двигателей внутреннего сгорания}

\author{
Е.А. Фролов, С.В. Попов, А.В. Сидорчук
}

Работа посвящена повышению надежности и долговечности деталей цилиндропоршневой группы двигателей внутреннего сгорания. Упрочнения деталей машин возможно за счет применения специальных технологических процессов. Современные материалы и покрытия должны удовлетворять высоким рабочим температурам и нагрузкам. Хромирование, борирование и ионно-плазменное напыление не удовлетворяют установленным требованиям качества. Алюминиевый поршень испытывает разрушений в районе головки. Это проявляется в накоплении щелей, каналов, следов вымывания сплава. Кроме этого, вследствие нагревания, теряется прочность алюминиевого сплава больше, чем в 2 раза.

Предложено создание и применение покрытия, которое бы выдерживало рабочие температуры более $2000^{\circ} \mathrm{C}$, а также ударно-пульсирующие нагрузки. Предлагается детонационно-газовый метод напыления. Он характеризуется универсальностью материалов: от полимеров до тугоплавкой керамики, любые металлы и сплавы. Напылённые частицы обладают высокой кинетической энергией. Покрытие характеризуется высокой прочностью, которая достигает 180...200 МПа, твердостью HRCe 60, минимальной пористостью. Температурное воздействие при напылении на заготовку незначительно. Предложена последовательность подготовительных операций. Упрочнению подлежали поршень и жаровое кольцо на детонационно-газовой установке «УН-102». Применялся манипулятор, использующий энергию выстрела установки. Полученные поверхности характеризуются регулярной макроструктурой (волнистостью). Нанесению подлежал никель-алюминиевый сплав. Толщиной покрытия - $150 \ldots 270$ мкм, твердость - HV 550, адгезия к основанию - 94...100 МПа.

Результаты исследований на деталях цилиндропоршневой группы показали снижение рабочих температур, вследствие приработки покрытия и качественного уплотнения камеры сгорания. Долговечность колец составляет $1,6 \cdot 10^{6} \ldots 2,3 \cdot 10^{6}$, что свидетельствует о значительном повышении сопротивления усталости и ресурса работы. Предложенная технология пригодна и рекомендуется к внедрению в серийное производство.

Ключевые слова: детонационно-газовое упрочнение, поршень, жаровое кольцо, напыление, покрытие.

ISSN 2311-1828

http://enm.khntusg.com.ua
Інженерія природокористування, 2020, №4(18), с. 24 - 28

Engineering of nature management, 2020, \#4(18), p. 24 - 28 


\section{Abstract \\ The operational parameters improving of internal combustion engine parts}

\section{E.A. Frolov, S.V. Popov, O.V. Sydorchuk}

The work is dedicated to improving the reliability and durability of parts of a piston cylinder group of internal combustion engines. Strengthening of machine parts is possible due to the application of special technological processes. Modern materials and coatings must meet high operating temperatures and loads. Chromium plating, boring and ion-plasma spraying do not meet the established quality requirements. The aluminium piston is destroyed in the area of the head. This is manifested in the accumulation of holes, channels, traces of alloy leaching. In addition, as a result of heating, the strength of the aluminium alloy is more than doubled.

It is proposed to create and apply a coating that can withstand operating temperatures above $2000^{\circ} \mathrm{C}$, as well as pulsating loads. A detonation and gas spraying method is proposed. It is characterized by the versatility of materials: from polymers to refractory ceramics, precious metals and alloys. The sawn particles have high kinetic energy. The coating is characterized by high strength, reaching up to $180 \ldots 200 \mathrm{MPa}$, HRCe 60 hardness, minimum width. The temperature influence during spraying on the work piece is negligible. A sequence of preparatory operations is proposed. The piston and the heat ring on the UN-102 detonation gas plant were subject to hardening. A manipulator using the shot energy of the installation was used. The obtained surfaces are characterized by regular macrostructure (waviness). The application was subject to a nickelaluminium alloy. The coating thickness is $150 \ldots 270$ microns, the hardness is HV 550, the adhesion to the base is $94 \ldots 100 \mathrm{MPa}$.

The results of the studies on the details of the cylindrical piston group showed a decrease in operating temperatures due to the finalization of the coating and the high-quality seal of the combustion chamber. The durability of the rings is $1.6 \cdot 106 \ldots 2.3 \cdot 106$, which indicates a significant increase in fatigue resistance and work life. The proposed technology is suitable and recommended for implementation in batch production.

Keywords: detonation-gas hardening, piston, heat ring, spraying, coating.

\section{Бібліографрічне посилання/ Bibliography citation: Harvard}

Frolov, E. A., Popov, S. V. and Sydorchuk, O. V. (2020) 'The operational parameters improving of internal combustion engine parts', Engineering of nature management, (4(18), pp. 24 - 28.

Подано до редакції / Received: 02.11.2020 